\title{
Educational Implications of the New Ideas in Library Construction
}

$\mathrm{T}$ HE NEW BUILDING methods and techniques that have educational implications, may be listed as follows:

I. Modular planning and dry construction

2. New methods of conditioning air

3. Improved lighting facilities

4. Less concern over the monumentality of buildings

5. Acceptance of the idea of a building that is friendly to man and nature.

Each of these may be briefly described:

I. Modular planning as it is being developed means simply that floor space approaches universal use. That is, any given floor area will accommodate, interchangeably, nearly all known library activitiesbook storage, seating for readers, library technical operations, use of special facilities, and instructional activities. The floor space also can accommodate new activities without involving complex or expensive structural operations. Dry construction means the use of floor, wall, and ceiling materials that are assembled, bolted, or otherwise fastened as units, not cemented or plastered as masses.

The first obvious result of this freedom in the use of interior space will be extensive experimentation in library arrangements and organizations and a very rapid disappearance of the standard pattern of organization. In the past, the librarian engaged in planning a new building did not dare experiment with a new idea because should his experiment fail his building would be

\footnotetext{
1 Paper presented at the meeting of the Association of College and Reference Libraries, Buffalo, June 18, I946.
}

worthless and he would be fired. Now he is free to try new ideas. If they fail, another arrangement can be followed. For instance, the blueprints of the Iowa building show at least six methods of arranging reading rooms. We intend to try all six and eventually discontinue the ones that prove undesirable.

Thus, it follows from the above that in the planning of a modular building it is not necessary to anticipate the use which the building will get during its entire life span. We can plan our buildings for their maximum usefulness today and allow the same privilege for the next generation. A secondary effect of this is that it will not force librarians and faculty committee members to spend two or three years of their valuable time planning a building. It will also tend to destroy the illusion that a librarian who has gone through one building program is automatically an expert.

Third, modular planning should create better relations between the librarian and the architect, because it should prevent each from interfering with the true function of the other. The architect will concern himself with layout of communication and service facilities, with architectural style and appearance, and with engineering problems. The librarian will lay out the floor plan, and no antagonism can develop between the two. And I do believe that architects can make money doing a modular library.

2. New techniques suggest that we can afford to have air conditioning. If that is 
true, we shall no longer need to force the mass of a building into a shape that permits natural cross ventilation.

3. The same is true of lighting. Modern lighting is now good enough to be selfsufficient. Rooms need not be placed along an exterior wall if we do not want them there.

4. There probably will still be monumental libraries-Gothic, Manhattan, Georgian, and otherwise-but the trend is somewhat away from them. Campus planners are coming to understand that the harmony between a building and the technology of its time is just as important and desirable, if not more so, than the harmonies in surface resemblances between two or more adjacent structures. Or, to put it differently, we are getting an adult attitude toward the esthetics of architecture.

5. Libraries that are friendly to man and to nature are less stiff, formal, forbidding, and stylized than existing building. They will have a tendency to wear their hearts on the front steps, they will be easy to get into, more fun to be in, more replete with the amenities of modern living habits, and not at all chaste. They will make full use of color, materials, and furniture. They will exude a human smell, not that of lifeless stone.

\section{Plan for Function}

The essence of this new freedom is that we are free to plan for function. But what function? The freedom itself imposes nothing and suggests no philosophy as a guide to our functions. That, as always, can come only from our understanding, desires, and imagination.

Judging from what I can see in the various programs now proposed, I think there are certain common assumptions or directions behind all of them.

First, we librarians are an "untamed" lot and we are no longer content to confine our interest to "collecting, preserving, and preparing for use," but we are now concerned with "use" and all that goes with the term. We are trying to create a working relationship between students and faculty that will give the nonlaboratory departments facilities comparable to those long enjoyed by the laboratory departments. Thus, terms like workshop, library-laboratory, reading laboratory, and "libratory" are now being used. Behind all of these plans is a striving for a new kind of intimate association among the three sides of the collegiate triangle: the teacher, the student, and the book.

Why? For some, merely to be in style. For some, to attract the attention of worthy donors. For others, the appeal of the new. One of us has said, to insure the presence of a mature and interested guide, while students are engaged in extracting facts from print and in converting these facts into principles. For it is while the student is reading that guidance is needed. That is the moment for discussion and exchange, which are as essential as is the laboratory assistant in the sciences. Our libraries have been laboratories without teachers. We librarians have not been teachers, we have merely been stock-room clerks, getting the salts and bromide when needed, but little more. We seem to be proposing to create working conditions in which it will be normal and easy to read and discuss at the right moment without distractive forces of time and place.

\section{Barriers in Humanities}

The barriers of time and space that now exist between the student and the faculty in the humanities and social sciences are so serious that most students never get over them at all. This is especially true in the larger universities. We consider this a great waste of human power, and our faith 
in the power of print and the professor is so great that we are willing to go to much trouble to bring them together.

Second, all of us have lived long enough to have witnessed the gradual retreat of the idea of unity in education from "liberal" education (a four-year idea) to general education (a two-year idea). And most of us are agreed that in a university it is proper to create special library facilities to house the general education program. Some draw the line between graduate and undergraduate, others between general education and specialized education.

Princeton, Pennsylvania, and the Massachusetts Institute of Technology do not believe in providing special quarters for this idea, their reasons being, I judge, that their students mostly come from cultured Eastern homes and from private secondary schools which equip them to be at home immediately in the contents of a university library. Harvard is thinking of an undergraduate library to house some one hundred thousand books and one thousand readers. So is Indiana. Kenyon College is thinking of a "World Room" that stresses the global dimension of liberal education. Iowa plans a "Heritage Library"-a visual presentation of the history of ideas, chronologically arranged, as a device for helping students fix in their minds the basic concepts that students must know before they can absorb general education or begin specialized education.

And so it goes. Librarians are counting on their buildings to do something more than passively house programs. They expect them to be programs.

\section{More Integration with Instruction}

Third, once you conceive of the library as a program, either you are properly meshed in the educational machinery of your institution or else you are spinning your own wheels. It looks to me as though in a few years there will more B. Lamar Johnsons or Evelyn Steele Littles in our midst. Likewise, I think it entirely possible and reasonable to consider the combination of librarian and graduate school dean. In the meanwhile, these programs will not go unless they are planned from the inside out, not just as declarations of good intention.

\section{Visual Aids Center}

Fourth, those of you who have read Paul Wendt's article on "A Center of AudioVisual Aids Service" (published in the May I, 1946, issue of Higher Education) will know quite clearly that we librarians have some straight thinking to do on the question of visual aids in the library.

Thus far, all of us have said that we want visual and auditory aids used in our libraries and we are providing rooms for them-or at least we think we are. We have thought of them simply as a new learning medium and, therefore, as legitimate library material. We have not held to a static definition of print. But Mr. Wendt tells us that we librarians have been enemies of visual aids, that we are too dumb or impractical to manage their use, that they must be handled by a separate independent agency which will buy, process, and prepare for use visual aids just as we do books. So in a little while there will be competition between the visual aid director and the library director for funds for instructional material. Our askings are made under the guidance of a faculty committee. Theirs are not. We are going to want to house slides and films in the library where readers can use them. They will want them elsewhere. What the student and the professor want, I do not know. I suggest that we ask them before we get further into this controversy. In the meanwhile, we are planning buildings that permit extensive use of the materials. 
Fifth, of course, we are planning libraries in which people can go and read by themselves and not be bothered by anyone. But also, we are trying to get in the building the human factor that will stimulate the student to assume the initiative in learning. Surely we can agree that one fault of our present system of lecturing to students in large classes is that it fosters a passive attitude toward learning. We stand for the idea that each person should dig out and organize his own materials, under guidance, of course-and print is his source material.

Sixth, our faculties are coming more and more to practice an organismic psychology of learning. Instead of relying upon a system of tests and examinations as the sole criterion for evaluating a student's knowledge and understanding, they deem it necessary to know a good deal about the total personality of the student. The kind of working relationships found, for instance, in the Princeton library will provide just the setting that is needed to enable the professor to see his student as a personality in action, often and in lifelike situations. Thus, I say that our libraries provide the right kind of setting for learning as the professor wants it.

Seventh, in most of our institutions we are witnessing the development of areas of concentration curricula to be imposed on the traditional major system, the purpose being, of course, to get more breadth and less specialization. Such an idea would seem to confirm the wisdom of the subject divisional idea in the library. This idea is no longer new, of course. Unfortunately, it has had to prove itself during the war years when abnormal conditions have prevailed. But even so, it seems to have established itself as a sensible method of presenting materials and a plan that permits a logical use of library subject specialists. In spite of its origin and of its use at Brown, the idea is finding less favor along the Atlantic seaboard than in the West and Midwest. Now that one courageous Eastern director has ventured into the hinterland, even beyond Chicago, who knows? It may be announced soon, like the Harvard general education, as a brand new thing.

\section{Library Specialization}

Eighth, the idea of library specialization has grown rapidly under the stimulation of MacLeish, Evans, Metcalf, Boyd, and others, and the idea has taken hold. If so, and if each library is to accept responsibility for building complete collections in certain fields, I believe this work can be done properly only if we establish a better partnership between the library acquisitions personnel and the subject specialists. And I believe this partnership will be easier to establish in those libraries that are contemplating the housing of teaching staffs adjacent to the subject collections than in the traditional libraries. And it will be easier in those libraries that are trying to organize themselves so that they can afford to develop library subject specialists who can work with the faculty on a realistic basis on the buying of books.

In summary, I have tried to list the new ideas in library planning and construction that have educational implications, and I have suggested what these implications might be. Then I have tried to state some of the uses to which library planners are going to put these libraries, with their flexibility, their humaneness, and their freedom. In such buildings, the quality and nature of the educational programs can be taken as a true measure of the librarians who live within the walls. 